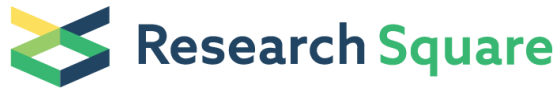 \\ Preprints are preliminary reports that have not undergone peer review. \\ They should not be considered conclusive, used to inform clinical practice, or referenced by the media as validated information.
}

\section{Surveillance Plan of Lipophilic Marine Biotoxins in Molluscs from the Croatian Coast}

\section{Tanja Bogdanovic}

Croatian Veterinary Institute

\section{Federica Di Giacinto}

Istituto Zooprofilattico Sperimentale dell'Abruzzo e del Molise G Caporale

\section{Miriam Berti}

Istituto Zooprofilattico Sperimentale dell'Abruzzo e del Molise G Caporale

\section{Pierina Visciano}

University of Teramo Faculty of Bioscience and Technology for Food, Agriculture and Environment

\section{Sandra Petričević}

Croatian Veterinary Institute

\section{Mario Rogošić}

Ministry of Agriculture and Fisheries

\section{Zoran Rogić}

Permanent Representation of the Republic of Croatia to the European Union

\section{Giuseppina Mascilongo}

Istituto Zooprofilattico Sperimentale dell'Abruzzo e del Molise G Caporale

\section{Ludovica Di Renzo}

Istituto Zooprofilattico Sperimentale dell'Abruzzo e del Molise G Caporale

\section{Nicola Ferri}

Istituto Zooprofilattico Sperimentale dell'Abruzzo e del Molise G Caporale

\section{Maria Schirone ( $\nabla$ mschirone@unite.it )}

University of Teramo Faculty of Bioscience and Technology for Food, Agriculture and Environment https://orcid.org/0000-0002-0999-1854

\section{Eddy Listes}

Croatian Veterinary Institute

\section{Research Article}

Keywords: okadaic acid, yessotoxin, azaspiracid, pectenotoxin, Adriatic Sea, Mytilus galloprovincialis, Callista chione

Posted Date: February 19th, 2021

DOI: https://doi.org/10.21203/rs.3.rs-210807/v1

License: (9) (i) This work is licensed under a Creative Commons Attribution 4.0 International License. Read Full License

Version of Record: A version of this preprint was published at Exposure and Health on August 17th, 2021. See the published version at https://doi.org/10.1007/s12403-021-00424-6. 


\section{Abstract}

In the present study, a 4-year surveillance plan for the detection of lipophilic marine biotoxins in Mytilus galloprovincialis and Callista chione from different aquaculture farms and natural beds along the Central Adriatic coasts of Croatia was reported. The samples were analyzed by a validated LC-MS/MS method in accordance with the Regulation (EU) No $2019 / 627$. Lipophilic marine biotoxins belonging to the okadaic acid group, except for azaspiracids, as well as yessotoxins were found at different concentrations, always below the maximum limits established by the Regulation (EC) No 853/2004. The seasonal distribution showed the highest values in summer months, and an interannual variability was also observed, probably due to environmental conditions aging on the density of harmful algal blooms. The comprehensive data reported in this study should help the future research in making advancing prediction models along the Eastern Adriatic coast.

\section{Introduction}

Marine biotoxins represent a sanitary problem worldwide as sources of foodborne diseases caused by consumption of contaminated molluscs. Besides food, the human exposure to these toxins can be linked to inhalation or skin contact (Visciano et al. 2016). They are produced by harmful algal blooms due to climate and sea surface temperature variations (Young et al. 2020) and are distinguished in hydrophilic and lipophilic marine biotoxins (Schirone et al. 2011). Many different compounds belong to the last group, such as okadaic acid (OA) and its analogues dinophysistoxins (DTX1, DTX2 and DTX3), that are the most common in the European countries (Alves et al. 2019) and together with azaspiracids (AZA1, AZA2 and AZA3) cause the diarrhetic shellfish poisoning (DSP) outbreaks, while pectenotoxins (PTXs) and yessotoxins (YTXs) are not proven to provoke such symptoms after their ingestion (Hassoun et al. 2021). The main symptoms of OA intoxication are nausea, vomiting, abdominal pain and diarrhea appearing within 30 min up to few hours and declining generally after 3 days (Dietrich et al. 2019). The toxicity of DTX1 is very similar to OA, whereas DTX2 and DTX3 are less toxic (Sitprija and Sitprija 2019). The azaspiracid poisoning (AZP) is characterized by nausea, diarrhea and stomach cramps occurring 3-18 hours after the consumption of contaminated molluscs, and the healing is within 2-5 days (Doerr et al. 2016). Even if PTXs and YTXs were included in DSP group, it has been recently demonstrated that they do not cause diarrhea after oral ingestion, but YTXs show paralytic effects on the cardiac muscle in mice (Bilbao et al. 2020) as well as dyspnea, jumping, tremors and spasms after intraperitoneal injection (Visciano et al. 2013).

The detection of marine biotoxins in molluscs collected along the Croatian coast of the Adriatic Sea started in the 1990s when OA was determined in shellfish from Kaštela Bay (Central Adriatic Sea). However, the toxin profile of Adriatic molluscs is complex, and the number of recorded toxic and potentially toxic species has increased over time. As reported by Arapov et al. (2013) on shellfish phycotoxin profile along Croatian coast of the Adriatic Sea, OA toxin group and YTXs are highlighted as the main lipophilic marine biotoxins, whereas PTXs have occasionally been found in Croatian molluscs at low concentrations (Ninčević Gladan et al. 2010; Ninčević Gladan et al. 2011). OA and DTXs are the most abundant and geographically widespread marine biotoxins, having been implicated in poisoning outbreaks or harvesting bans in Japan (Yasumoto et al. 1978; Suzuki and Watanabe 2012), China (Li et al. 2012), around the Mediterranean Sea (Prassopoulou et al. 2009; Ninčević Gladan et al. 2011; Ciminiello et al. 2014), along the western European coast (Kumagai et al. 1986; Ramstad et al. 2001; Vale et al. 2003; García et al. 2015), Great Britain (Hinder et al. 2011), Ireland (Carmody et al. 1995), Canada (Taylor et al. 2013), United States (Deeds et al. 2010), Mexico (García-Mendoza et al. 2014) and Argentina (Turner and Goya 2015). In literature during 21st century (2001-2015) more than 1200 and 200 cases are reported for DSP and AZP, respectively (Nicolas et al. 2017). Moreover, a total of 29 studies for DSP syndrome referred to all continents, mostly in Europe, were detailed by Young et al. (2020). The same authors described 3 case reports for AZP after the consumption of mussels produced in Ireland, the United States, and the Netherlands.

The monitoring programme in Croatia was established in the year 2000. Sampling plans to check for the presence of marine biotoxins and the sampling frequency for toxin analysis in live bivalve molluscs in Croatia are in accordance with the Regulation (EU) No 2019/627, even if they are set annually based on the national legislation. The official analytical methods 
to be used for the detection of marine biotoxins in molluscs has been set by the Regulation (EU) No 15/2011 since 31 December 2014 and is performed by liquid chromatography-mass spectrometry (LC-MS/MS). The method has been validated by the European Union Reference Laboratory for Marine Biotoxins (EURLMB) within its network of National Reference Laboratories (NRLs) and Official Control Laboratories (OCLs). The mouse bioassay (MBA) and the rat bioassay (RBA) have been successfully substituted by the LC-MS/MS method due to low specificity and detection capability, and wide range of obtained results. Moreover, as co-occurrence of marine biotoxins can be found in molluscs, alternative methods to the mouse bioassay are required for the proper identification of each analogue (Schirone et al., 2013; García et al. 2018; Schirone et al. 2018).

In year 2012, a European grant was assigned to a network of Adriatic laboratories and competent authorities coordinated by the Croatian Veterinary Institute (CVI). This project entitled "Strengthening of Centres for Aquaculture Production and Safety surveillance in the Adriatic Cross-border Countries - CAPS2" (www.caps2.eu) harmonised the management of all production areas of molluscs in the Adriatic Sea thanks to shared methodologies and techniques. The competent authorities were supported by the CAPS2 information system provided by a Web GIS for data querying and visualization. It was developed by the Istituto Zooprofilattico Sperimentale dell'Abruzzo e del Molise "G. Caporale" and available at http://www.caps2.eu/caps2/ (Tora et al. 2017). The database is filled by authorized users in accordance with the privileges assigned to each profile. In particular, the Ministry of Croatia, as competent authority, fixes the location and the boundaries of production and relaying areas and defines their classification; the CVI Laboratory feed the database with test results.

The objective of this study was the determination of lipophilic marine biotoxins in Mytilus galloprovincialis and Callista chione collected from different aquaculture farms and natural beds along the Central Adriatic coasts of Croatia and managed by new CAPS2 web tools. The sampling was carried out from January 2016 to December 2019 according to the multi-annual control plan which requires a weekly sampling frequency.

\section{Methods}

\section{Sample collection}

According to the national surveillance plan, specimens of $M$. galloprovincialis and $C$. chione were taken from different sampling areas shown in Fig. 1.

The sampling plan from 2016 to 2019 was reported in Table 1. A total of 1977 samples (Table 2) was examined by the Veterinary Institute of Split - Croatian Veterinary Institute. 
Table 1

Sampling sites distinguished for year and category of collection

\begin{tabular}{|c|c|c|c|c|c|c|}
\hline \multirow[t]{2}{*}{ Sampling sites } & \multirow[t]{2}{*}{ Area Code in the CAPS2 WEB-GIS } & \multirow[t]{2}{*}{ Category } & \multicolumn{4}{|l|}{ Year } \\
\hline & & & 2016 & 2017 & 2018 & 2019 \\
\hline Košara B1 & P-29-KO & $\mathrm{PA}^{*}$ & $x$ & $x$ & $x$ & $x$ \\
\hline Modrič - Seline B1 & P-08-MS & PA & $x$ & $x$ & $x$ & $x$ \\
\hline Obinuš B1 & P-32-BO & PA & & & $x$ & $x$ \\
\hline Paški kanal B1 & I-24-PK & $H A^{\star \star}$ & & $x$ & $x$ & $x$ \\
\hline Pirovac B1-Tatinja B1 & P-10-PZ & PA & $x$ & $x$ & $x$ & $x$ \\
\hline Sibenik B1 & P-11-URK-01 & PA & $x$ & $\mathrm{x}$ & $x$ & $x$ \\
\hline Stara Povljana B1 & P-07-USP & PA & $x$ & $x$ & $x$ & $x$ \\
\hline Strmica B2 & P-11-URK-07 & PA & $x$ & $x$ & $x$ & $x$ \\
\hline Sv. Ante B1 & I-20-KSA & $\mathrm{HA}$ & $x$ & $x$ & $x$ & $x$ \\
\hline Uvala Dumičina B1 & P-09-NM & PA & $x$ & $x$ & $x$ & $x$ \\
\hline Uvala Dumičina M2 & P-09-NM-02 & PA & $x$ & & & \\
\hline Uvala Maslinova B1 & P-24-UMA & PA & $x$ & $x$ & $x$ & $x$ \\
\hline Uvala Stara Povljana B1 & I-18-PO & $\mathrm{HA}$ & $x$ & & & \\
\hline Uvala Dinjiška B1 & P-31-DNJ & PA & & $x$ & $x$ & $x$ \\
\hline Velebitski kanal B1 & I-25-VK & $\mathrm{HA}$ & & $x$ & $x$ & $x$ \\
\hline
\end{tabular}

Table 2

Number of samples distinguished for years and mollusc species

\begin{tabular}{|llllll|}
\hline Number & $\mathbf{2 0 1 6}$ & $\mathbf{2 0 1 7}$ & $\mathbf{2 0 1 8}$ & $\mathbf{2 0 1 9}$ & Total \\
\hline Mussels (Mytilus galloprovincialis) & 370 & 416 & 466 & 514 & 1766 \\
\hline Smooth clams (Callista chione) & 0 & 60 & 84 & 67 & 211 \\
\hline Total & 370 & 476 & 550 & 581 & 1977 \\
\hline
\end{tabular}

In the laboratory, the flesh of molluscs was washed with running water, homogenized with a blender and stored at $-20^{\circ} \mathrm{C}$ until the analysis. Two $\mathrm{g}$ of the homogenate per each sample was used for the lipophilic marine biotoxins determination.

\section{Chemicals And Sample Preparation}

The following reagents: methanol and acetonitrile (LC-MS grade), hydrochloric acid (37\% purity), formic acid (98\%), sodium hydroxide (99\%) and ammonium formate (99\%) were taken from Sigma-Aldrich (St. Louis, MO, USA). The water at highpurity grade was obtained from a Milli- $Q^{R}$ system (Merck Millipore, Darmstadt, Germany). The stock standard solutions were prepared in methanol at concentrations of $200 \mu \mathrm{g} / \mathrm{l}$ for AZA (AZA1, AZA2 and AZA3), OA, DTX1, DTX2 and PTX2 and at $500 \mu \mathrm{g} / \mathrm{l}$ for YTX and 1-Homo-YTX. The certified reference standards were purchased from the Certified Reference Materials Program of the Institute for Marine Biosciences, National Research Council Canada (Ottawa, Ontario, Canada). They were constituted in solutions of OA (CRM-OA c), DTX1 (CRM-DTX1) and DTX2 (CRM-DTX2), PTX2 (CRM PTX2), AZA1 (CRM-AZA1), AZA2 (CRM-AZA2), AZA3 (CRM-AZA3), YTX (CRM-YTX), 1-Homo YTX (CRM-Homo YTX), certified reference 
material with OA, and DTX (CRM DSP- MUS-b), homogenate of the digestive gland of mussel (Mytilus edulis) with OA and DTX and freeze-dried mussels tissue homogenate of $M$. edulis (RM-FDMT) containing DA, OA, DTX1, DTX2, AZA1, AZA2, AZA3, PTX2, YTX, and SPX-1. The calibration curve for the marine biotoxins was prepared in blank mussels tissue extracts (MUS-Zero, National Research Council Canada, Ottawa, Ontario, Canada) due to the presence of matrix effects in concentrations ranging from 1.5 to $40 \mu \mathrm{g} / \mathrm{I}$ for AZA-, OA- and PTX-group, and 3.75-100 $\mu \mathrm{g} / \mathrm{l}$ for YTX-group following the EU-harmonized Standard Operating Procedure (Brańa-Magdalena et al. 2014; EURLMB SOP 2015).

Samples and blank mussel material were extracted using the procedure described in EURLMB SOP (2015). Two $\mathrm{g}$ of the homogenized sample was accurately weighed into a $50 \mathrm{ml}$ centrifuge tube. Nine $\mathrm{ml}$ of methanol were added, and the samples were extracted by rigorous shaking on a vortex mixer (Werke, Staufen, Germany) for 3 min. After centrifugation (Hettich Rotina 420R, Tuttlingen, Germany) for 10 min at $20^{\circ} \mathrm{C}$ the supernatant was transferred to a 20 ml volumetric flask, and the remaining tissue pellet was extracted again by adding $9 \mathrm{ml}$ methanol and using a high-speed homogenizer (UltraTurrax T 25 Basic (IKA Werke, Staufen, Germany). After centrifugation at the same conditions described above, the supernatant of the second extraction was combined with the first extract and methanol. Free OA, DTX1, DTX2, PTXs, AZAs were quantified in this crude extract. To determine the total content of OA and DTXs, $1 \mathrm{ml}$ of the crude extracts was hydrolysed with $125 \mu \mathrm{l} 2.5 \mathrm{M} \mathrm{NaOH}$ solution at $76^{\circ} \mathrm{C}$ for $40 \mathrm{~min}$. Afterwards, the extract was neutralized by adding $125 \mu \mathrm{l} 2.5$ $\mathrm{M} \mathrm{HCl}$ solution and homogenized by vortex mixing for $0.5 \mathrm{~min}$. Both extracts, with and without hydrolysis, were diluted with mobile phase A (1/1) filtered through a PVDF filter with a pore size of $0.2 \mu \mathrm{m}$ filter (PVDF Membrane; Membrane Solutions, Millipore, Cork, Ireland) before the analysis.

The extraction of DSP toxins was conducted as recommended by EURLMB SOP (2015); $1.9 \mathrm{~g}$ CRM-DSP-MUS-b was accurately weighed, transferred into a $50 \mathrm{ml}$ centrifuge tube, and extracted following the procedure described above. Dilutions of 1:50 and 1:6 of the extract were prepared by transferring $400 \mu \mathrm{l}$ and $3.3 \mathrm{ml}$, respectively, of the crude extract into a $20 \mathrm{ml}$ volumetric flask with methanol. Reconstitution of the FDMT was carried out following the procedure recommended by the manufacturer (NRC-CNRC). FDMT $(0.35 \mathrm{~g}$ ) was reconstituted in a $50 \mathrm{ml}$ centrifuge tube by adding $1.65 \mathrm{ml}$ deionized water, followed by vortex mixing for $30 \mathrm{sec}$ and sonication for $1 \mathrm{~min}$ in an ultrasonic bath (Selecta; Ultrasonic-OR, Barcelona, Spain). The extraction of the lipophilic marine biotoxins was carried out according to the method described previously.

\section{Method Validation}

The method used for the biotoxin analysis was validated according to the criteria laid down in Regulation (EU) No 2019/627. The performance assessment criteria included the limit of detection (LOD), the limit of quantification (LOQ), repeatability, reproducibility, specificity, linearity and recovery. Specificity was tested by analysing 20 representative blank samples (M. galloprovincialis, $C$. chione). No potential interfering compounds were found at the retention times of interest. These blank samples were used to evaluate the LOD and LOQ of the method. They were calculated based on a $S / N>3$ and $S / N>10$, respectively, using triplicate injections $(n=3)$ of standard solutions at concentrations next to the limits. The response linearity was calculated from the five-point calibration curve prepared in matrix matched standards (MMs) in a blank mussel extract using the standard area $(y)$ against the analytes concentration $(x)$. The linearity of the standard calibration curve was determined by calculating ratio $\mathrm{y} / \mathrm{x}$ for each experimental point, average of the ratios $(\mathrm{y} / \mathrm{x})$ and by checking that all calibration points fell in the range of average $(y / x)$ values $\pm 10 \%$. The ratio $(y / x)$ for each calibration curve did not deviate more than $10 \%$ of the average ratio value that resulted below the target concentration established by the EU harmonized SOP (2015). The response linearity was calculated from the five-point calibration curve prepared in both methanol and MMs in a blank mussel extract at concentrations ranging from 1.5 to $40 \mu \mathrm{g} / \mathrm{l}$ for AZA-, OA- and PTX- group, and 3.75-100 $\mu \mathrm{g} / \mathrm{l}$ for YTX-group using the standard area (y) against the analytes concentration (x).

The calibration curve was linear in the given range with a coefficient of determination $\left(R^{2}\right)$ of 0.999 . The repeatability and reproducibility were determined by fortifying blank mussel at three selected levels (three replicates for each level) reported in Table 3. A negative sample spiked with all biotoxins for six samples at three levels in two different days considering the 
maximum limits and the TEF to calculate the TEQ (Toxicity Equivalent Quantitation) was used to calculate the recovery. In detail, the mussel samples were spiked with OA-, DTX-group and AZA- group at concentrations of 45, 68 and $90 \mu \mathrm{g} / \mathrm{kg}$, and with YTX-group at concentrations of 937, 1875 and $2812.5 \mu \mathrm{g} / \mathrm{kg}$. For each marine biotoxins, the mean recovery of a 36sample set was calculated and used for the accuracy assessment, evaluated based on the intra-laboratory coefficient of variation. The measurement uncertainty was calculated according to EURACHEM/CITAC Guide CG4 (2012) and shown in Table 4. The coefficient of variation ranged from 2.3 to 19.8. The recovery for all tested levels was between 78.5 and 120.8 $\%$.

Table 3

The reproducibility data

\begin{tabular}{|c|c|c|c|c|c|c|c|c|c|c|c|c|}
\hline \multirow[t]{2}{*}{ Biotoxin } & \multirow[t]{2}{*}{ Linearity } & \multirow[t]{2}{*}{ LOD } & \multirow[t]{2}{*}{ LOQ } & \multicolumn{3}{|c|}{ First level $(n=12)$} & \multicolumn{3}{|c|}{ Second level $(n=12)$} & \multicolumn{3}{|c|}{ Third level $(n=12)$} \\
\hline & & & & Recovery & SD & CV & Recovery & SD & CV & Recovery & SD & CV \\
\hline OA & 0.999 & 15 & 30 & 120.7 & 11.3 & 9.3 & 110.1 & 4.9 & 4.5 & 115.5 & 14.0 & 12.1 \\
\hline DTX1 & 0.999 & 15 & 30 & 83.7 & 10.0 & 11.9 & 103.7 & 14.6 & 14.1 & 104.8 & 6.3 & 6.0 \\
\hline DTX2 & 0.999 & 15 & 30 & 93.1 & 2.1 & 2.3 & 78.9 & 4.5 & 5.6 & 80.6 & 5.8 & 7.2 \\
\hline PTX2 & 0.990 & 7.5 & 15 & 100.9 & 4.3 & 4.3 & 84.8 & 6.8 & 8.0 & 91.9 & 5.8 & 6.3 \\
\hline AZA1 & 0.991 & 7.5 & 15 & 109.0 & 7.6 & 6.9 & 104.1 & 14.9 & 14.3 & 91.5 & 15.7 & 17.1 \\
\hline AZA2 & 0.992 & 7.5 & 15 & 85.6 & 14.0 & 16.4 & 106.4 & 7.0 & 6.6 & 86.0 & 4.9 & 5.7 \\
\hline AZA3 & 0.990 & 7.5 & 15 & 101.6 & 6.6 & 6.5 & 101.7 & 8.4 & 8.3 & 98.7 & 8.9 & 9.0 \\
\hline YTX & 0.995 & 14.6 & 18.7 & 101.9 & 16.8 & 16.5 & 103.9 & 20.6 & 19.8 & 95.7 & 18.6 & 19.5 \\
\hline $\begin{array}{l}\text { 1-Homo } \\
\text { YTX }\end{array}$ & 0.992 & 18.7 & 75 & 87.1 & 14.1 & 16.2 & 80.1 & 11.3 & 14.1 & 78.5 & 5.4 & 7.9 \\
\hline
\end{tabular}

Table 4

Measurement uncertainty

\begin{tabular}{|ll|}
\multicolumn{2}{|c|}{$(\mathrm{MU})$} \\
\hline Biotoxin & $\mathrm{MU}(\%)$ \\
\hline OA & 11.6 \\
\hline DTX1 & 23.0 \\
\hline DTX2 & 17.0 \\
\hline PTX2 & 16.0 \\
\hline AZA1 & 6.0 \\
\hline AZA2 & 15.0 \\
\hline AZA3 & 26.0 \\
\hline YTX & 11.0 \\
\hline 1-Homo YTX & 11.0 \\
\hline
\end{tabular}

\section{Uhplc/ms/ms Analysis}


The chromatographic separation was carried out using an Agilent Technologies (Waghaeusel-Wiesental, Germany) 1290 Infinity UHPLC system consisting of a binary pump, a high-performance autosampler, and a thermostat column compartment. Lipophilic marine biotoxins were separated by gradient elution using an Agilent ZORBAX SB-octylsilyl (C8) Rapid Resolution High Definition column $(50 \times 2.1 \mathrm{~mm}$ id, $1.8 \mu \mathrm{m}$ particle size $)$ at $40^{\circ} \mathrm{C}$. The mobile phase $\mathrm{A}$ was water $(100$ $\%)$ and $B$ was acetonitrile:water (95:5, v/v), both containing $2 \mathrm{mM}$ ammonium formate and $50 \mathrm{mM}$ formic acid. A gradient program with a flow rate of $0.2 \mathrm{ml} / \mathrm{min}$ was run starting with 0.5 min isocratic at $30 \% \mathrm{~B}$, followed by a linear gradient to $90 \%$ $B$ in $8 \mathrm{~min}$. After an isocratic hold time of $3 \mathrm{~min}$ at $90 \% \mathrm{~B}$, a linear gradient was applied to return to the starting conditions of $30 \% \mathrm{~B}$ in $0.5 \mathrm{~min}$. The total run time was $15 \mathrm{~min}$, and an equilibration time of $3.5 \mathrm{~min}$ was allowed before the next injection. The samples in the autosampler were cooled to $7^{\circ} \mathrm{C}$.

The LC-MS/MS analysis was carried out by a mass spectrometer Agilent G6460A (Waghaeusel-Wiesental, Germany) equipped with an electrospray interface (Agilent Jet Stream ESI source, Agilent Technologies) set in the positive ionization mode (ESI+) for AZA-, OA- and PTX-group and the negative ionization mode (ESI-) for YTX group. The mass spectrometer was set in multiple reaction monitoring (MRM) mode, with specific transition parameters as reported in Table 5. The capillary voltage was set at $4.5 \mathrm{kV}$ for ESI+, $5.0 \mathrm{kV}$ for ESI-. A drying gas flow of $7 \mathrm{I} / \mathrm{min}$ at a temperature of $200^{\circ} \mathrm{C}$, a nebulizer gas pressure of 27 psi (Nitrogen Generator System, Peak Scientific, Scotland, UK), and a sheath gas (nitrogen $99.999 \%$ pure, Messer, Dugi Rat, Croatia), the flow of $11 \mathrm{l} / \mathrm{min}$ at a temperature of $350^{\circ} \mathrm{C}$ were chosen. For those lipophilic marine biotoxins for which no reference standards were available, the parameters were adjusted according to those optimized for their structurally related commercially available toxin. Two MRM transitions were set up for all toxins. The transition with the higher intensity was used for quantification, while the transition with the lower intensity was used for confirmation purposes. 
Table 5

LC-MS/MS parameters for lipophilic marine biotoxins detection in MRM mode

\begin{tabular}{|c|c|c|c|c|c|c|}
\hline Biotoxin & ESI & $\begin{array}{l}\text { Precursor ion } \\
(\mathrm{m} / \mathrm{z})\end{array}$ & $\begin{array}{l}\text { Product ion } \\
(\mathrm{m} / \mathrm{z})\end{array}$ & $\begin{array}{l}\text { Fragmentor } \\
\text { (V) }\end{array}$ & $\begin{array}{l}\text { Collision energy } \\
\text { (V) }\end{array}$ & Cell accelerator $(\mathrm{V})$ \\
\hline \multirow[t]{2}{*}{ OA } & \multirow[t]{2}{*}{+} & \multirow[t]{2}{*}{827.4} & 809.3 & 300 & 44 & \multirow[t]{2}{*}{7} \\
\hline & & & 723.3 & 300 & 50 & \\
\hline \multirow[t]{2}{*}{ DTX2 } & \multirow[t]{2}{*}{+} & \multirow[t]{2}{*}{827.4} & 809.6 & 260 & 46 & \multirow[t]{2}{*}{5} \\
\hline & & & 723.3 & 260 & 50 & \\
\hline \multirow[t]{2}{*}{ DTX1 } & \multirow[t]{2}{*}{+} & \multirow[t]{2}{*}{841.4} & 823.5 & 290 & 46 & \multirow[t]{2}{*}{7} \\
\hline & & & 737.4 & 290 & 54 & \\
\hline \multirow[t]{2}{*}{ PTX2 } & \multirow[t]{2}{*}{+} & \multirow[t]{2}{*}{876.4} & 213.1 & 130 & 44 & \multirow[t]{2}{*}{5} \\
\hline & & & 194.9 & 130 & 54 & \\
\hline \multirow[t]{2}{*}{ PTX1 } & \multirow[t]{2}{*}{+} & \multirow[t]{2}{*}{892.7} & 821.4 & 170 & 25 & \multirow[t]{2}{*}{5} \\
\hline & & & 213 & 170 & 42 & \\
\hline \multirow[t]{2}{*}{ YTX } & \multirow[t]{2}{*}{-} & \multirow[t]{2}{*}{1141.4} & 1061.3 & 260 & 30 & \multirow[t]{2}{*}{1} \\
\hline & & & 855.4 & 260 & 78 & \\
\hline \multirow[t]{2}{*}{ 1-Homo YTX } & \multirow[t]{2}{*}{-} & \multirow[t]{2}{*}{1155.4} & 1075.6 & 260 & 30 & \multirow[t]{2}{*}{1} \\
\hline & & & 869 & 260 & 80 & \\
\hline \multirow[t]{2}{*}{ 450HYTX } & \multirow[t]{2}{*}{-} & \multirow[t]{2}{*}{1157.5} & 1077.5 & 260 & 30 & \multirow[t]{2}{*}{1} \\
\hline & & & 871.5 & 260 & 80 & \\
\hline \multirow[t]{2}{*}{ 450H-Homo YTX } & \multirow[t]{2}{*}{-} & 1171.8 & 1091.5 & 230 & 30 & 1 \\
\hline & & & 869.4 & 230 & 80 & \\
\hline AZA1 & + & 842.4 & 824.4 & 260 & 30 & 1 \\
\hline & & & 806.5 & 260 & 42 & \\
\hline AZA2 & + & 856.5 & 838.6 & 270 & 30 & 1 \\
\hline & & & 820.4 & 270 & 42 & \\
\hline AZA3 & + & 828.4 & 810.5 & 240 & 28 & 3 \\
\hline
\end{tabular}

\section{Results And Discussion}

During the surveillance plan conducted from January 2016 to December 2019, less than $1 \%$ of all samples resulted contaminated by lipophilic marine biotoxins belonging to the OA-group at concentrations ranging from 25.6 to $87.0 \mu \mathrm{g} / \mathrm{kg}$, and $65 \%$ of samples positive only to OA showed this compound in the esterified form (Table 6). It is well known that both OA and DTX2 can be found in free or esterified forms (Alves et al. 2019) and the different proportion of them could arise from the genetic variability of bivalve molluscs, since the OA esterification is an enzymatic mechanism associated with the detoxification process (Prassopoulou et al. 2009). 
Table 6

Concentrations $(\mu \mathrm{g} / \mathrm{kg})$ of lipophilic marine biotoxins belonging to OA-group in sampling sites along the Croatian coasts

\begin{tabular}{|c|c|c|c|c|c|c|c|c|c|}
\hline \multirow{2}{*}{$\begin{array}{l}\text { Sampling } \\
\text { sites }\end{array}$} & \multirow[t]{2}{*}{ Month/Year } & \multicolumn{3}{|c|}{ Free OA group toxin } & \multicolumn{5}{|c|}{ Total OA group toxin } \\
\hline & & $O A$ & DTX1 & DTX2 & OA & DTX1 & DTX2 & PTX1 & PTX2 \\
\hline P-09-NM & $02 / 2016$ & & & & 37.5 & 25.6 & & & \\
\hline $\begin{array}{l}\text { P-11-URK- } \\
07\end{array}$ & $03 / 2016$ & & & & 49.9 & & 48.3 & & \\
\hline $\begin{array}{l}\text { P-11-URK- } \\
01\end{array}$ & $03 / 2016$ & & & & 51.2 & & 47.9 & & \\
\hline $\begin{array}{l}\text { P-11-URK- } \\
01\end{array}$ & $06 / 2016$ & 34.0 & & & 77.0 & & & & \\
\hline P-24-UMA & $06 / 2016$ & & & & 53.0 & & & & \\
\hline I-20-KSA & $06 / 2016$ & & & & 47.0 & 36.0 & & & \\
\hline P-29-KO & $06 / 2016$ & 33.0 & & & 76.0 & & & & \\
\hline P-29-KO & $05 / 2018$ & 60.0 & & & 70.0 & & & & \\
\hline I-18-PO & $05 / 2018$ & 58.4 & & & 74.6 & & & & \\
\hline P-31-DNJ & $08 / 2018$ & & & & & & 87.0 & & \\
\hline P-31-DNJ & 02/2019 & & & & & & & 59.3 & \\
\hline P-08-MS & $02 / 2019$ & & & & & & & 54.3 & \\
\hline $\begin{array}{l}\text { P-09-NM- } \\
02\end{array}$ & $02 / 2019$ & & & & & & & 57.7 & \\
\hline P-32-BO & $02 / 2019$ & 57.1 & & & & & & & 60.9 \\
\hline $\begin{array}{l}\text { P-11-URK- } \\
07\end{array}$ & 02/2019 & 56.6 & & & 76.4 & & & & 60.7 \\
\hline P-08-MS & $06 / 2019$ & & & & 74.0 & & & & \\
\hline
\end{tabular}

OA was found to be present at higher concentrations in the hydrolysed extracts, with relative proportions of free and esterified form showing the dominance of the last. In detail, OA was detected in the hydrolysed extracts of 11 samples, up to a maximum of $77 \mu \mathrm{g} / \mathrm{kg}$. Neither DTX1 nor DTX2 were detected in any of the non-hydrolysed extracts, but within the samples included in the total OA-group, co-occurrence of OA and DTX1 or DTX2 was identified in 4 samples (Table 6).

The detection of PTX1 in February 2019 represents the first report of this toxin along the Croatian coastline. PTXs have been reported since the 1990s on both coasts of the Adriatic Sea, with the first PTX2 report in Europe in phytoplankton species Dinophysis fortii along the Emilia-Romagna coast of Italy (Draisci et al. 1996). A rare PTX2 derivative, 7-epi-pectenotoxin-2 seco acid (7-epi-PTX2SA) was the only toxin detected in samples from the Central Adriatic Sea (Pavela-Vrančić et al. 2002). In molluscs, PTX2 is metabolised into PTX2 seco acid (PTX2SA), 7-epi-PTX2SA (Suzuki et al. 2001; Miles et al. 2004) and PTX2SA esters (Wilkins et al. 2006). Blanco et al. (2019) supposed that the underrepresentation of PTX2 in Galician bivalve molluscs was related to the fast conversion of PTX2 to seco acid and several other esters, but such metabolites were not checked in our study.

The interannual variability observed in the present study could be a combination of different factors including the cell density of harmful algal bloom, cell toxin profile, toxin quota, biological and environmental factors, climate conditions as well (Dhanji-Rapkova et al. 2018; Ninčević Gladan et al. 2020). In the study of Ninčević Gladan et al. (2020), some species of 
Dinophysis genus were observed during spring (Dinophysis caudata, Dinophysis sacculus), summer (D. fortii, D. sacculus) and autumn (D. fortii, Phalacroma rotundatum) in the Šibenik bay. Bacchiocchi et al. (2015) described seasonal variations in Dinophysis cell abundance in the North-Central Adriatic Sea during a 2-year monitoring study (from March 2012 to February 2014) with maximum levels recorded in June-July and October-November. This seasonal trend respected the phytoplankton dynamic of this area, showing two annual increases, in spring/early summer, due to high irradiance and stratification, and in autumn for the increased inflow of nutrients from the Po River. In particular, the authors reported a major OA-group contamination in mussels collected in autumn-winter of year 2013 from the Northern area of the Marche region coast, probably due to the proximity of the Po River delta, which represents the most important source of eutrophication of the Adriatic Sea. In our study, the highest distribution of lipophilic marine biotoxins of the OA-group was observed in summer months (Table 6).

With regards to AZAs, the sampling sites investigated in our study did not report these compounds and such result was in accordance with the data observed by Schirone et al. (2018). On the contrary, other authors reported AZA2 presence in samples of M. galloprovincialis collected from the Bay of Neum (Bosnia and Herzegovina) and the Makarska City Bay (Croatia) during June-December 2017, at concentrations slightly above the LOD, with a maximum value of 3.5 and 3.8 $\mu \mathrm{g} / \mathrm{kg}$, respectively (Talić et al. 2020). However, the first report of AZA2 in mussels from the North-Central Adriatic Sea was described by Bacchiocchi et al. (2015) even if only in trace amounts.

YTX and 45-OH-YTX were the most frequently detected toxins in the examined samples, both in M. galloprovincialis and $C$. chione. Their concentrations ranged from $0.030 \mathrm{mg} / \mathrm{kg}$ in C. chione in October 2017 to $1.375 \mathrm{mg} / \mathrm{kg}$ in M. galloprovincialis in October 2018 (data not shown). According to other investigations carried out along the Adriatic coastline since 2004, YTXs are the most frequently determined toxins (Ninčević Gladan et al. 2008; Čustović et al. 2009; Ninčević Gladan et al. 2010). Their detection in shellfish from the Northern Adriatic Sea was related to the presence of Lingulodinium polyedrum (Ninčević Gladan et al. 2008; Ninčević Gladan et al. 2010). The toxin production by L. polyedrum and Gonyaulax spinifera isolated from the Adriatic Sea was confirmed by Pistocchi et al. (2012) and Riccardi et al. (2009).

Moreover, YTX was partially transformed into 45-OH-YTX, as confirmed by other studies (Aasen 2005; Blanco et al. 2019). Within the investigated $C$. chione samples, $45-\mathrm{OH}-\mathrm{YTX}$ was detected only in one sample, probably due to a substantially lower rate of transformation than in mussels, whereas it was found in $30 \%$ of samples of M. galloprovincialis. 1-Homo-YTX was observed twice in August 2018, while 45-OH-Homo-YTX was detected once in June of the same year, always in $M$. galloprovincialis (data not shown).

As each group of lipophilic marine biotoxins is constituted of many toxic analogues, the regulatory limits are established based on their total toxicity. According to the Regulation (EC) No 853/2004, they correspond to $160 \mu \mathrm{g}$ of OA equivalents/kg for OA-, DTX- and PTX-group together, $160 \mu \mathrm{g}$ of AZA equivalents $/ \mathrm{kg}$ and $3.75 \mathrm{mg}$ of YTX equivalent/ $\mathrm{kg}$ for AZA- and YTXgroup, respectively. No sample examined in the present study exceeded the regulatory limits as shown in Figs. 2 and 3 . This result was in contrast with other studies reported in literature. Schirone et al. (2018) found OA concentrations exceeding the maximum limit in 11 (4.3\%) samples of $M$. galloprovincialis from different mollusc plants located along the Central Adriatic coast, and some samples showed the simultaneous presence of OA, YTX and 1-Homo-YTX. Also, Alves et al. (2019) and Bilbao et al. (2020) reported OA-group concentrations above the maximum regulatory limit in different species of shellfish from Ireland and the Portuguese coast, and the Spanish Basque coast, respectively.

\section{Conclusions}


It is widely known that the accumulation of marine biotoxins in molluscs is a dynamic phenomenon influenced by numerous environmental variables. In this study, YTX- and OA- group were the main lipophilic marine biotoxins found at quantifiable levels, but well below their corresponding regulatory limits. Such result demonstrated the good condition of the investigated marine areas as well as the safety of bivalve molluscs collected from the Croatian coast. If compared with other areas worldwide, such as Ireland, Portugal, Norway, and Scotland coasts where high levels of OA-group toxins have been reported, our results indicated that the problem of phycotoxin presence along the Eastern Adriatic Sea does not pose a serious threat for human health. However, due to occasional toxic episodes reported in the past, a regular monitoring of phycotoxins is necessary to prevent human intoxication. Moreover, as the Adriatic Sea represents a semi-enclosed and vulnerable environment, special attention regarding the risk of introducing harmful aquatic organisms through vessel ballast water (Rak et al. 2019) must be paid. The comprehensive data presented in this study should help the future research in making advancing prediction models along the Eastern Adriatic coast. Finally, the LC-MS/MS method applied in this study was able to define both presence and concentrations of lipophilic marine biotoxins, which must be routinely monitored to avoid the risk of exposure in regular as well as strong consumers of bivalve molluscs.

\section{Declarations}

\section{Acknowledgements}

The authors would like to thank the Croatian Ministry of Agriculture, the Veterinary and Food Safety Directorate

Compliance with Ethical Standards Not applicable

Conflict of interest The authors declare that they have no conflict of interest.

\section{References}

Aasen J, Samdal IA, Miles CO, Dahl E, Briggs LR, Aune T (2005) Yessotoxins in Norwegian Blue Mussels (Mytilus edulis): Uptake from Protoceratium reticulatum, metabolism and depuration. Toxicon 45(3):265-272.

Alves RN, Rambla-Alegre M, Braga AC, Maulvault AL, Barbosa V, Campàs M, Reverté L, Flores C, Caixach J, Kilcoyne J, Costa PR, Diogène J, Marques A (2019) Bioaccessibility of lipophilic and hydrophilic marine biotoxins in seafood: An in vitro digestion approach. Food Chem Toxicol 129:153-161.

Arapov J (2013) A review of shellfish phycotoxin profile and toxic phytoplankton species along Croatian coast of the Adriatic Sea. Acta Adriat 54(2):283-298.

Bacchiocchi S, Siracusa M, Ruzzi A, Gorbi S, Ercolessi M, Cosentino MA, Ammazzalorso P, Orletti R (2015) Two-year study of lipophilic marine toxin profile in mussles of the North-central Adriatic Sea: first report of azaspiracids in Mediterranean seafood. Toxicon 108:115-125.

Bilbao J, Muñiz O, Revilla M, Rodríguez JG, Laza-Martínez A, Seoane S (2020) Suitability of two area of the Basque coast to sustain shellfish aquaculture according to the both presence of potentially toxic phytoplankton and the biotoxins regulated by the European Union. Reg Stud Mar Sci, 36:101279.

Blanco J, Arévalo F, Correa J, Moroño A (2019) Lipophilic toxins in Galicia (NW Spain) between 2014 and 2017: Incidence on the main molluscan species and analysis of the monitoring efficiency. Toxins 11(612):1-23.

Braña-Magdalena A, Leão-Martins JM, Glauner T, Gago-Martínez A (2014) Intralaboratory validation of a fast and sensitive UHPLC/MS/MS method with fast polarity switching for the analysis of lipophilic shellfish toxins. J AOAC Int 97(2):285-292. 
Carmody EP, James KJ, Kelly SS, Thomas K (1995) Complex diarrhetic shellfish toxin profiles in Irish mussels. In: P. Lassu P, G. Arzul, E. Erard, P. Gentien P, C. Marcaillou (Eds). Harmful Marine Algal Blooms. Proceedings of the $6^{\text {th }}$ International Conference on toxic marine phytoplankton. October 18-22, Nantes, France. pp. 273-278.

Ciminiello P, Dell'Aversano C, Forino M, Tartaglione L (2014) Marine toxins in Italy: the more you look, the more you find. Eur J Org Chem 1357-1369.

Deeds JR, Wiles K, Heideman GB, White KD, Abraham A (2010) First U.S. report of shellfish harvesting closures due to confirmed okadaic acid in Texas Gulf coast oysters. Toxicon 55(6):1138-1146.

Dhanji-Rapkova M, O’Neill A, Maskrey BH, Coates L, Teixeira Alves M, Kelly RJ, Hatfield RG, Rowland-Pilgrim SJ, Lewis AM, Algoet M, Turner AD (2018) Variability and profiles of lipophilic toxins in bivalves from Great Britain during five and a half years of monitoring: Okadaic acid, dinophysis toxins and pectenotoxins. Harmful Algae 77:66-80.

Dietrich J, Grass I, Günzel D, Herek S, Braeuning A, Lampen A, Hessel-Pras S (2019) The marine biotoxin okadaic acid affects intestinal tight junction proteins in human intestinal cells. Toxicol in Vitro 58:150-160.

Doerr B, O'Halloran J, O'Brien N, van Pelt F (2016) Investigation of the genotoxic potential of the marine biotoxins azaspiracid 1-3. Toxicon, 121:61-69.

Draisci R, Lucentini L, Giannetti L, Boria P, Poletti R (1996) First report of pectenotoxin-2 (PTX-2) in algae (Dinophysis fortii) related to seafood poisoning in Europe. Toxicon 34:923-935.

EURLMB (European Union Reference Laboratory for marine Biotoxins) (2015) EU-Harmonised Standard Operating Procedure for determination of Lipophilic marine biotoxins in molluscs by LC-MS/MS. Version 5, 1-33.

http://www.aecosan.msssi.gob.es/CRLMB/docs/docs/metodos_analiticos_de_desarrollo/EU-Harmonised-SOP-LIPO-

LCMSMS_Version5.pdf

García C, Pérez F, Contreras C, Figueroa D, Barriga A, López-Rivera A, Araneda OF, Contreras HR (2015) Saxitoxins and okadaic acid group: Accumulation and distribution in invertebrate marine vectors from Southern Chile. Food Addit Contam:

Part A 6:984-1002.

García-Mendoza E, Sánchez-Bravo YA, Turner A, Blanco J, O’Neil A, Mancera-Flores J, Pérez-Brunius P, Rivas D, AlmazánBecerril A, Peña-Manjarrez JL (2014) Lipophilic toxins in cultivated mussels (Mytilus galloprovincialis) from Baja California, Mexico. Toxicon 90: 111-123.

Hassoun AER, Ujević I, Mahfouz C, Fakhri M, Roje-Busatto R, Jemaa S, Nazlić N (2021) Occurrence of domoic acid and cyclic imines in marine biota from Lebanon-Eastern Mediterranean Sea. Sci Total Environ 755:142542.

Hinder SL, Hays GC, Brooks CJ, Davies AP, Edwards M, Walne AW, Gravenor MB (2011) Toxic marine microalgae and shellfish poisoning in the British isles: history, review of epidemiology, and future implications. Environ Health 10:54.

Kumagai M, Yanagi T, Murata M, Yasumoto T, Kat M, Lassus P, Rodriguez-Vazquez JA (1986) Okadaic acid as the causative toxin of diarrhetic shellfish poisoning in Europe. Agric Biol Chem 50(11):2853-2857.

Li A, Ma J, Cao J, McCarron P (2012) Toxins in mussels (Mytilus galloprovincialis) associated with diarrhetic shellfish poisoning episodes in China. Toxicon 60(3):420-425.

Miles CO, Wilkins AL, Munday R, Dines MH, Hawkes AD, Briggs LR, Sandvik M, Jensen DJ, Cooney JM, Holland PT, Quilliam MA, Mackenzie AL, Beuzenberg V, Towers NR (2004) Isolation of pectenotoxin-2 from Dinophysis acuta and its conversion to pectenotoxin-2 seco acid, and preliminary assessment of their acute toxicities. Toxicon 43(1):1-9.

Page $12 / 17$ 
Nicolas J, Hoogenboom RLAP, Hendriksen PJM, Bodero M, Bovee TFH, Rietjens IMCM, Gerssen A (2017) Marine biotoxins and associated outbreaks following seafood consumption: Prevention and surveillance in the $21^{\text {st }}$ century. Glob Food Sec 15:11-21.

Ninčević Gladan Ž, Matić F, Arapov J, Skejić S, Bužančić M, Bakrač A, Straka M, Dekneudt Q, Grbec B, Garber R, Nazlić N (2020). The relationship between toxic phytoplankton species occurrence and environmental and metereological factors along the Eastern Adriatic coast. Harmful Algae 92:101745.

Ninčević Gladan Ž, Skejić S, Bužančić M, Marasović I, Arapov J, Ujević I, Bojanić N, Grbec B, Kušpilić G, Vidjak O (2008) Seasonal variability in Dinophysis spp. abundances and diarrhetic shellfish poisoning outbreaks along the eastern Adriatic coast. Botanica Marina 51, 449-463.

Ninčević Gladan Ž, Ujević I, Milandri A, Marasović I, Ceredi A, Pigozzi S, Arapov J, Skejić S, Orhanović S, Isajlović I (2010) Is yessotoxin the main phycotoxin in Croatian waters? Mar Drugs 8(3):460-470.

Ninčević Gladan Ž, Ujević I, Milandri A, Marasović I, Ceredi A, Pigozzi S, Arapov J, Skejić S (2011) Lipophilic toxin profile in Mytilus galloprovincialis during episodes of diarrhetic shellfish poisoning (DSP) in the N.E. Adriatic Sea in 2006. Molecules 16(1):888-899.

Pavela-Vrančić M, Meštrović V, Marasović I, Gillman M, Furey A, James KJ (2002). DSP toxin profile in the coastal waters of the central Adriatic Sea. Toxicon 40:1601-1607.

Pistocchi R, Guerrini F, Pezzolesi L, Riccardi M, Vanucci S, Ciminiello P, Dell'Aversano C, Forino M, Fattorusso E, Tartaglione L, Milandri A, Pompei M, Cangini M, Pigozzi S, Riccardi E (2012) Toxin levels and profiles in microalgae from the North-Western Adriatic Sea - 15 years of studies on cultured species. Mar Drugs 10:140-162.

Prassopoulou E, Katikou P, Georgantelis D, Kyritsakis A (2009) Detection of okadaic acid and related esters in mussels during diarrhetic shellfish poisoning (DSP) episodes in Greece using the mouse bioassay, the PP2A inhibition assay and HPLC with fluorimetric detection. Toxicon 53:214-227.

Rak G, Zec D, Kostelac MM, Joksimović D, Gollasch S, David M (2019) The implementation of the ballast water management convention in the Adriatic Sea through States' cooperation: The contribution of environmental law and institutions. Mar Pollut Bull 147:245-253.

Ramstad H, Hovgaard P, Yasumoto T, Larsen S, Aune T (2001) Monthly variations in diarrhetic toxins and yessotoxin in shellfish from coast to the inner part of the Sognefjord, Norway. Toxicon 39(7):1035-1043.

Riccardi M, Guerrini F, Roncarati F, Milandri A, Cangini M, Pigozzi S, Riccardi E, Ceredi A, Ciminiello P, Dell'Aversano C, Fattorusso E, Forino M, Tartaglione L, Pistocchi R (2009) Gonyaulax spinifera from the Adriatic sea: Toxin production and phylogenetic analysis. Harmful Algae 8:279-290.

Schirone M, Berti M, Visciano P, Chiumiento F, Tofalo R, Di Giacinto F, Migliorati G, Suzzi G, Ferri N (2018) Determination of lipophilic marine biotoxins in mussels harvested from the Adriatic Sea by LC-MS/MS. Front Microbiol 9:152.

Schirone M, Berti M, Zitti G, Ferri N, Tofalo R, Suzzi G, Visciano P (2011) Monitoring of marine biotoxins in Mytilus galloprovincialis of Central Adriatic Sea (2006-2009). Ital J Food Sci 23:431-435.

Schirone M, Visciano P, Luciani M, Ciarelli A, Berti M, Tofalo R, Suzzi G (2013) Yessotoxin determination in Mytilus galloprovincialis revealed by an in vitro functional assay. Environ Sci Pollut Res 20:1189-1192.

Sitprija V, Sitprija S (2019). Marine toxins and nefrotoxicity: Mechanism of injury. Toxicon 161:44-49.

Page $13 / 17$ 
Suzuki T, Mitsuya T (2001) Comparison of dinophysistoxin-1 and esterified dinophysistoxin-

1 (dinophysistoxin-3) contents in the scallop Patinopecten yessoensis and the mussel Mytilus galloprovincialis. Toxicon 39:905-908.

Suzuki T, Watanabe R (2012) Shellfish toxin monitoring system in Japan and some Asian countries. In: AG Cabado, Vieites JM (Eds), New trends in marine and freshwater toxins: Food and safety concerns. Chapter 10: 305-314. Nova Science Publishers, Inc., New York. ISBN: 978-1-61470-324-2.

Talić S, Škobić D, Dedić A, Nazlić N, Ujević I, Ivanković A, Pavela-Vrančić M (2020) The occurrence of lipophilic toxins in shellfish from the Middle Adriatic Sea. Toxicon 186:19-25.

Taylor M, McIntyre L, Ritson M, Stone J, Bronson R, Bitzikos O, Rourke W, Galanis E (2013) Outbreak of diarrhetic shellfish poisoning associated with mussels, British Columbia, Canada. Mar Drugs 11(5):1669-1676.

Tora S, Sacchini S, Listeš E, Bogdanović T, Di Lorenzo A, Smajlović M, Smajlović A, Filipović JV, Tahirović V, Šuković D, Beljkas B, Xinxo A, Maçi R, Colangeli P, Di Giacinto F, Conte A (2017) A geographical information system for the management of the aquaculture data in the Adriatic Sea - the strengthening of centres for aquaculture production and safety surveillance in the Adriatic countries experience: Present capabilities, tools and functions. Geospat Health 12(593):300-308.

Turner AD, Goya AB (2015) Occurrence and profiles of lipophilic toxins in shellfish harvested from Argentina. Toxicon 102:32-42.

Vale P, Maia AJ, Correia A, Rodrigues SM, Botelho MJ, Casanova G, Silva A, Vilarinho MG, Silva AD (2003) An outbreak of diarrhetic shellfish poisoning after ingestion of wild mussels at the northern coast in summer 2002. Electron J Environ Agric Food Chem 2(4):449-452.

Visciano P, Schirone M, Berti M, Milandri A, Tofalo R, Suzzi G (2016) Marine biotoxins: occurrence, toxicity, regulatory limits and reference methods. Front Microbiol 7:1051.

Visciano P, Schirone M, Tofalo R, Berti M, Luciani M, Ferri N, Suzzi G (2013) Detection of yessotoxin by three different methods in Mytilus galloprovincialis of Adriatic Sea, Italy. Chemosphere 3:1077-1082.

Wilkins A, Rehmann N, Torgersen T, Rundberget T, Keogh M, Petersen D, Hess P, Rise F, Miles CO (2006) Identification of fatty acid esters of pectenotoxin-2 seco acid in blue mussels (Mytilus edulis) from Ireland. J Agric Food Chem 54:5672-5678.

Yasumoto T, Oshima Y, Yamaguchi M (1978) Occurrence of a new type of shellfish poisoning in the Tokohu district. Bull Jap Soc Sci Fish 44(11):1249-1255.

Young N, Sharpe RA, Barciela R, Nichols G, Davidson K, Berdalet E, Fleming LE (2020) Marine harmful algal blooms and human health: A systematic scoping review. Harmful Algae 98:101901.

\section{Figures}




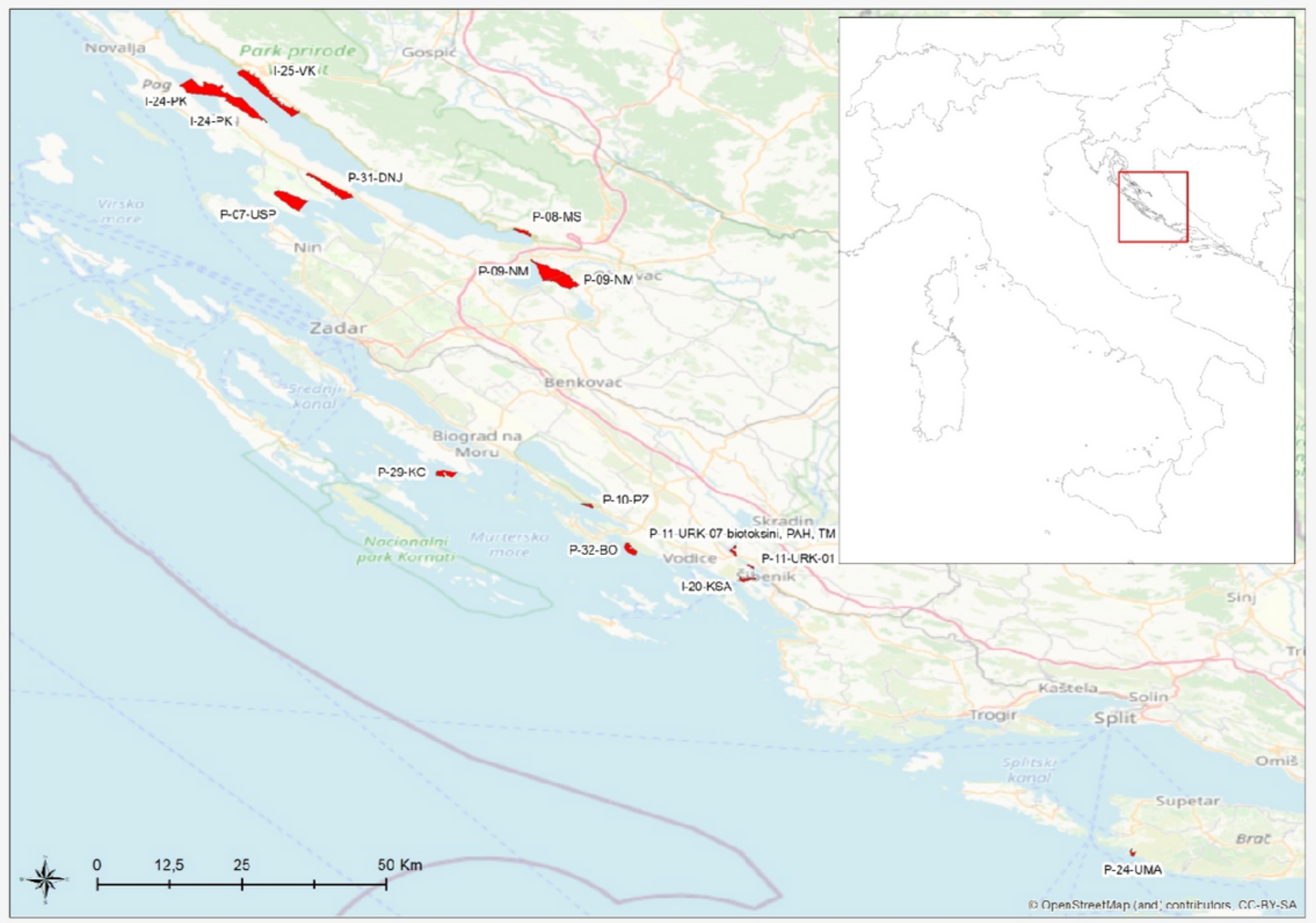

\section{Figure 1}

Map of the Croatian coast illustrating the sampling sites Note: The designations employed and the presentation of the material on this map do not imply the expression of any opinion whatsoever on the part of Research Square concerning the legal status of any country, territory, city or area or of its authorities, or concerning the delimitation of its frontiers or boundaries. This map has been provided by the authors. 


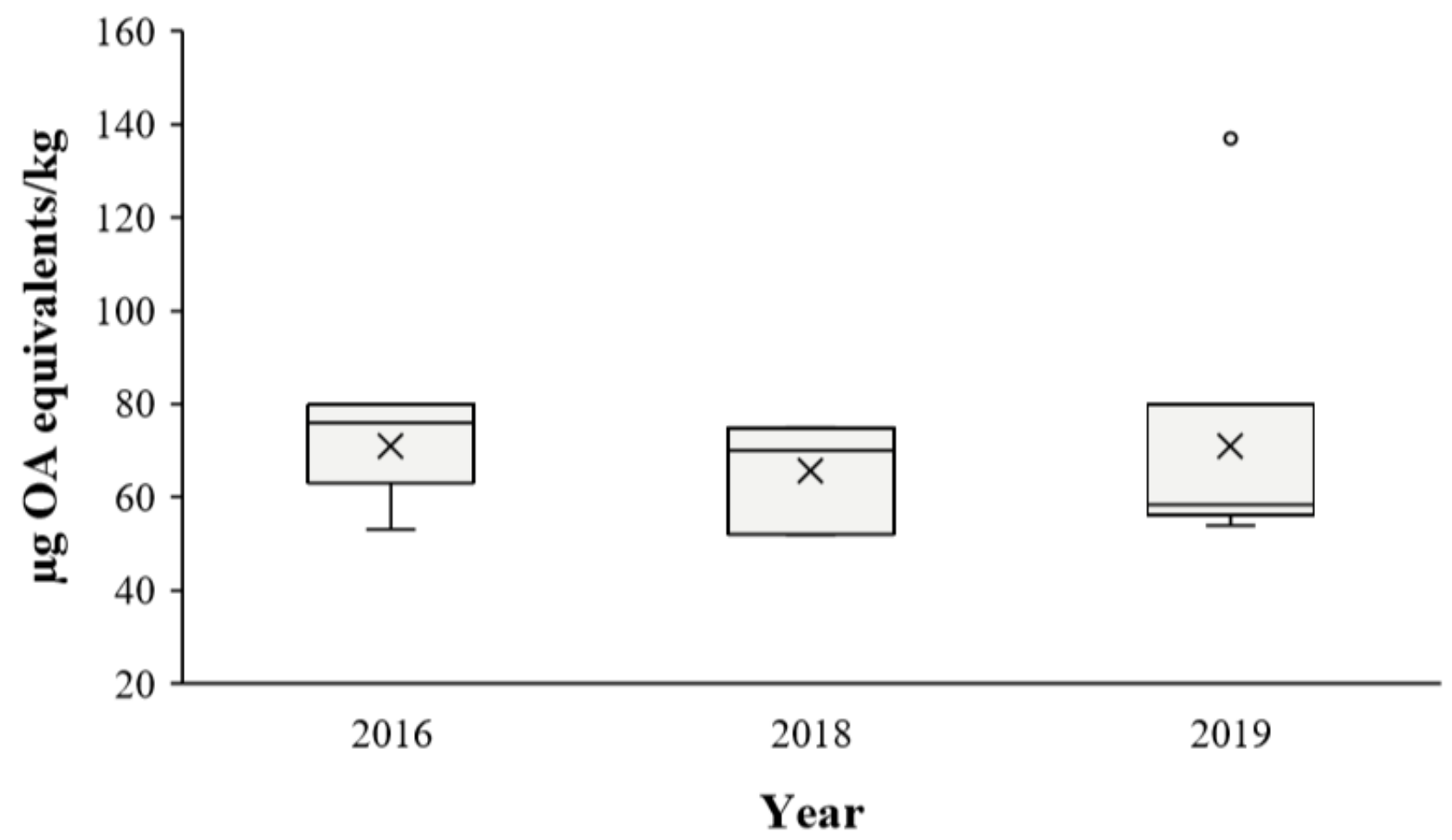

Figure 2

Temporal trend of okadaic acid (OA) expressed as $\mu \mathrm{g}$ OA equivalents/ $\mathrm{Kg}$ in molluscs collected from the Croatian coast

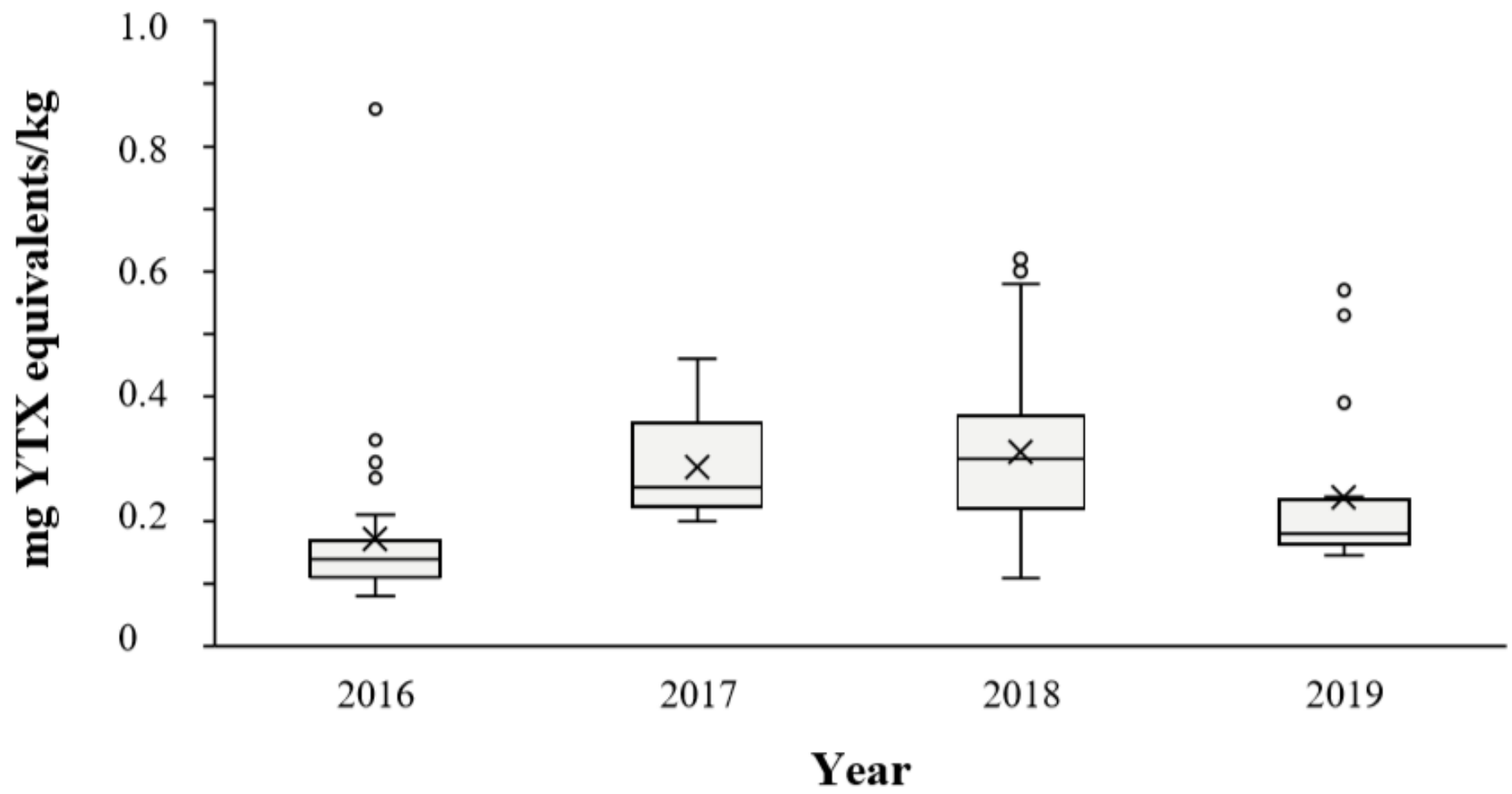

Figure 3 
Temporal trend of yessotoxin (YTX) expressed as mg YTX equivalents/Kg in molluscs collected from the Croatian coast 